\title{
Municipal waste incinerators: air and biological monitoring of workers for exposure to particles, metals, and organic compounds
}

\author{
A Maître, D Collot-Fertey, L Anzivino, M Marques, M Hours, M Stoklov
}

See end of article for authors' affiliations

\section{Correspondence to:}

Dr A Maître, Department of Occupational Medicine, EPSP-TIMC Laboratory, Grenoble University Medical School, Domaine de la Merci, 38700 La Tronche, France:

Anne.Maitre@ujf-grenoble.fr

Accepted 12 September 2002

\begin{abstract}
Aims: To evaluate occupational exposure to toxic pollutants at municipal waste incinerators (MWIs). Methods: Twenty nine male subjects working near the furnaces in two MWls, and 17 subjects not occupationally exposed to combustion generated pollutants were studied. Individual air samples were taken throughout the shift; urine samples were collected before and after. Stationary air samples were taken near potential sources of emission.

Results: Occupational exposure did not result in the infringement of any occupational threshold limit value. Atmospheric exposure levels to particles and metals were 10-100 times higher in $\mathrm{MWls}$ than at the control site. The main sources were cleaning operations for particles, and residue transfer and disposal operations for metals. MWI workers were not exposed to higher levels of polycyclic aromatic hydrocarbons than workers who are routinely in contact with vehicle exhaust. The air concentrations of volatile organic compounds and aldehydes were low and did not appear to pose any significant threat to human health. Only the measurement of chlorinated hydrocarbon levels would seem to be a reliable marker for the combustion of plastics. Urine metal levels were significantly higher at plant 1 than at plant 2 because of high levels of pollutants emanating from one old furnace.

Conclusion: While biological monitoring is an easy way of acquiring data on long term personal exposure, air monitoring remains the only method that makes it possible to identify the primary sources of pollutant emission which need to be controlled if occupational exposure and environmental pollution are to be reduced.
\end{abstract}

$\mathrm{H}$ ow to treat household waste is a major concern in industrialised countries in which it is being generated in ever increasing amounts. In France, the amount generated has doubled in the past 40 years to reach an annual average of $400 \mathrm{~kg}$ per person, which corresponds to a total of 20 million tonnes a year across the country. ${ }^{1}$ While by the year 2002, only final wastes will be allowed to be stored, the main focuses of disposal policy are reducing the amount generated, recycling, and destruction. Almost $50 \%$ of current waste is incinerated in nearly 300 different facilities which employ a total of 15000 staff. The quantity incinerated will increase, especially in big plants with effective pollution control equipment and efficient energy recovery units.

The management of solid waste, particularly the role of incineration, is currently a subject of heated public debate. ${ }^{2}$ While incineration is a good means of reducing the volume of waste and eliminating certain infectious components, metals (especially lead, manganese, cadmium, chromium, and mercury) are concentrated in fly and bottom ashes. Furthermore, incomplete combustion produces a wide variety of potentially hazardous organic compounds (such as aldehydes, chlorinated hydrocarbons, polycyclic aromatic hydrocarbons (PAHs), polychlorinated dibenzodioxins, and dibenzofuranes). ${ }^{2}$ Many of these hazardous substances are carcinogenic and some have direct systemic toxicity. ${ }^{3}$ Respiratory problems and reduced male fertility have been reported in the population surrounding an incinerator, but in every case, the culprit has been identified as an older facility. ${ }^{45}$ While some environmental studies have revealed a correlation between residence close to an MWI and the incidence of various types of cancer (including lung cancer, liver cancer, soft tissue sarcoma, and haematopoietic cancer), ${ }^{6-8}$ the impact on human health of carcinogenic emissions from newer MWIs was found to be so minimal that the role of other factors could not be ruled out. ${ }^{9-11}$ By virtue of the efficiency of modern effluent treatment systems, the concentrations of metals and organic compounds in the fallout of emissions from newer incinerators are so low that they cannot be resolved from the baseline signal. ${ }^{12} 13$

In contrast to the comprehensive environmental studies, little work has been carried out on the employees of MWIs who work in proximity to the furnaces and who are therefore directly exposed to both the gases released during combustion and to solid residues-that is, bottom and fly ash residues. Acute respiratory problems ${ }^{14}{ }^{15}$ are mainly caused by chemical pollutants, which are also responsible for the mutagenic activities detected in the urine of these workers ${ }^{16}$; exposure to microorganisms and endotoxins is mainly a problem in other sectors of the waste disposal industry, notably garbage collection, sorting, landfilling, and composting. The results of epidemiological studies conducted to investigate carcinogenicity are inconsistent: a retrospective cohort study conducted on 532 male workers in Italy ${ }^{17}$ identified an increased incidence of stomach but not of lung cancer, whereas a Swedish study ${ }^{18}$ recorded increased mortality-although the difference was insignificant-among 176 MWI workers as well as among other populations exposed to combustion products. ${ }^{19}$ In addition to fact that the size of the populations studied is necessarily limited because of the small numbers of workers in incineration facilities, the failure to characterise individual

Abbreviations: $\mathrm{AAS}$, atomic absorption spectrometry; $\mathrm{BEI}$, biological exposure index; HPLC, high performance liquid chromatography; IP, inhalable particles; $M W I$, municipal waster incinerator; $\mathrm{PAH}$, polycyclic aromatic hydrocarbon; RP, respirable particles; TLV, threshold limit value; TWA, time weighted average; VOC, volatile organic compound 
exposure levels is an important methodological shortcoming of the studies conducted hitherto.

The aims of this work are to identify the possible sources of emission of pollutants in MWIs and to compare the exposure of workers in these facilities with that of other subjects not employed in MWIs. Individual and stationary air sampling techniques were used to monitor the main toxic gaseous and particulate pollutants (apart from volatile mercury and the dioxins, for which air sampling and testing is difficult). ${ }^{2}$ Internal levels of organic and inorganic compounds were also estimated in all subjects by measuring the concentrations of various urinary metabolites before and after their shifts. This work is the first part of a multidisciplinary approach to investigate the health of MWI workers. ${ }^{20}$

\section{MATERIALS AND METHODS \\ MWI and control site}

This study was carried out in two MWIs, both located in urban surroundings and using recovered energy for local heating networks and electricity generation. The nature of the incinerated waste was different at the two sites: at the first site (plant 1), hospital waste was regularly incinerated and preliminary sorting for recyclable materials was carried out, whereas the second site (plant 2) only dealt with routine household waste without any preliminary sorting. Plant 1 was built in 1971, but major technical modifications to bring it up to line with current norms had been being implemented since 1993. It is equipped with three rotary kilns, each with a waste incineration capacity of 8 tonnes per hour. At the time of the study, one old furnace was still in use, although two others had already been replaced with machines with effective electrostatic precipitators and liquid lime and soda scrubbers (for the removal of acidic gases and sulphur dioxide). The second incinerator, which was newly built in 1989, is equipped with three grate furnaces, each with a capacity of 12 tonnes per hour and fitted with efficient electrostatic precipitators and liquid lime scrubbers. In both plants, the combustion chamber temperature varied between 850 and $1060^{\circ} \mathrm{C}$, and the decontaminated exhaust was released into the atmosphere via a 50 metre high chimney. Bottom ash residues were transported by vibrating conveyors and stored in a bunker; fly ashes collected from the flue gas treatment system were removed by a screw conveyor into big-bags at plant 1 , and into a storage silo at plant 2 . All ash residues were subsequently transported in trucks for final disposal in landfill.

To assess baseline atmospheric levels, a control site was selected, namely a supermarket near the same town. The MWI and control site were more than $10 \mathrm{~km}$ apart.

\section{MWI workers and control subjects}

Plants 1 and 2 employed 39 and 44 workers respectively. Since neither managers nor administrative staff were included in the study, the study population consisted of 29 male volunteers; 15 from plant 1 and 14 from plant 2 . They worked in proximity to waste incineration operations. The work stations and jobs concerned were as follows: waste reception controllers $(n=2)$, crane drivers $(n=4)$, incinerator conductors $(n=7)$, mechanics and electricians $(n=3)$, refuse feed hopper operatives $(n=3)$, ash residue transfer and disposal operatives $(n=7)$, and flue gas scrubbing operatives $(n=3)$. Waste reception controllers are responsible for supervising the transfer of refuse from truck to bunker and cleaning the reception hall. Crane drivers operate mobile cranes with clamshell grabs used to transfer refuse into the feed chutes of the furnaces. Incinerator conductors monitor processes in the control room and work together with an electrician or mechanic to identify technical problems and maintain equipment. Refuse feed hopper operatives are responsible for keeping the feed hopper clear and therefore work extremely close to the furnace; in addition, at plant 1 , this operative controls the tipping of hospital refuse containers into the feed chutes. Ash residue transfer and disposal operatives work directly on the vibrating conveyors and are responsible for the loading of residues into trucks by means of overhead cranes; at plant 1 , this operative is also responsible for removing full big-bags and replacing them with empty ones. Finally, flue gas scrubbing operatives control fume treatment systems and water quality testing.

The control population comprised 17 male supermarket employees working in direct contact with customers or in offices.

\section{Air sampling and analysis}

The study was conducted over two time periods: one of one week in January 1995 for plant 1; one of two weeks in November 1995 for plant 2 and the control site. At the MWIs, individual airborne pollutant exposure levels were monitored for 16 types of worker: waste reception controllers $(n=1)$, incinerator conductors $(\mathrm{n}=5)$, mechanics or electricians $(\mathrm{n}=2)$, refuse feed hopper operatives $(\mathrm{n}=2)$, ash residue transfer and disposal operatives $(\mathrm{n}=5)$, and flue gas scrubbing operatives $(\mathrm{n}=1)$. In addition, 20 air sampling points were monitored: inside the control room-that is, the crane driver's work station $(\mathrm{n}=3)$ and various points close to potential sources of toxic emissions; near the refuse bunker in the reception hall $(\mathrm{n}=5)$; on the refuse feed hopper platform $(\mathrm{n}=6)$; in the big-bag area $(\mathrm{n}=3)$; and at the solid residue transfer station $(\mathrm{n}=3)$. In the control site, various samples were taken by employees working in the supermarket's aisles $(\mathrm{n}=3)$ and offices $(\mathrm{n}=3)$.

During the eight hour shift, stationary and individual air samples were taken using the same active sampling devices at both incinerators as at the control site. On their collars, workers wore sampling devices connected to battery operated sampling pumps carried on their belts. Portable air sampling devices positioned at $1.5 \mathrm{~m}$ from the ground were used for stationary sampling. The flow rate of each sampling pump was set using a flow rate meter before use, and checked after sampling at the end of the shift. If the drift in sampling rate was greater than 5\%, the sample was rejected. Inhalable and respirable particles (IP and RP), inorganic elements, aldehydes, and volatile organic compounds (VOCs) were sampled at all the sites. PAH samples were taken at plant 2 and at the control site.

All air sampling and test methods were in accordance with the French reference methods as defined for industrial workplaces, and have been described in detail elsewhere. ${ }^{21}$ In the particulate phase, IP and RP were selectively sampled with quartz fibre filters in closed face cassettes, both without and with a cyclone mounted on the inlet side of the filter holder. For each sample, a control filter was weighed at the same time before and after sampling. Metals were collected using quartz fibre filters with a sampling rate of $1 \mathrm{l} / \mathrm{min}$. After acid extraction, inorganic elements-arsenic (As), cadmium (Cd), chromium $(\mathrm{Cr})$, lead $(\mathrm{Pb})$, manganese $(\mathrm{Mn})$, and nickel (Ni) -were assayed by atomic absorption spectrometry (AAS). Particulate PAHs were collected on PTFE filters and, after solvent extraction and concentration, were analysed by high performance liquid chromatography (HPLC) with a fluorescence detection system. Nine PAHs were quantified: fluoranthene (FLA), pyrene (PYR), benzo(a)anthracene $(\mathrm{BaA})$, chrysene $(\mathrm{CHR})$, benzo(b)fluoranthene $(\mathrm{BbF})$, ben$\mathrm{zo}(\mathrm{k})$ fluoranthene $(\mathrm{BkF})$, benzo(a)pyrene $(\mathrm{BaP})$, dibenzo(a,h)anthracene (DahA), and benzo(ghi)perylene (BghiP). Aldehydes were collected on solid silica gel coated with 2,4-dinitrophenylhydrazine with a sampling rate of $1 \mathrm{l} / \mathrm{min}$. After solvent extraction and concentration, formaldehyde, acetaldehyde, propionaldehyde, and acroleine were quantified using HPLC with an ultraviolet detection system. VOCs were collected on activated charcoal tubes with a sampling flow rate 
of $100 \mathrm{ml} / \mathrm{min}$. Analysis was carried out by capillary gas chromatography with flame ionisation detection. Aliphatic, cyclic, and aromatic hydrocarbons, and chlorinated and oxygenated hydrocarbons were all quantified. Our laboratory is accredited for the sampling and the analysis of benzene and lead by the French Department of Labour.

\section{Biological sampling and analysis}

Urine samples were collected for all the subjects at the beginning and end of each shift over the same week as the air monitoring. Metals were analysed by AAS. Our laboratory participates in the National Institute of Public Health of Quebec external quality control system for metals. The levels of $\mathrm{Cd}, \mathrm{Cr}$, and Ni were measured in the urine of all subjects. Mn and inorganic As metabolite levels were only measured in the employees of plant 2 and the control site. The metabolites of organic substances were analysed using gas chromatography with flame ionisation detection for 0 -cresol (OC), and HPLC: with fluorescence detection for 1-hydroxypyrene (1-HP); and with ultraviolet detection for t,t-muconic acid (TMA) and methylhippuric acid (MHA). Urine concentrations of OC and MHA were measured for all subjects, whereas 1-HP and TMA were only assayed in the employees of plant 2 and the control site. Subjects with undetectable urine levels were allocated the mid-value of the lowest analytical detection limit for each compound.

\section{Data analysis}

The main sources of emission for each pollutant were determined from air levels. Individual air and biological concentrations were compared to the French occupational threshold limit value (TLV), respectively the time weighted average (TWA) and the biological exposure index (BEI). All TLVs were specified in tables of results. Statistical analysis was conducted using the SPSS for Windows statistical software program (SPSS Inc., Chicago, IL, USA). A Mann-Whitney two-independent-samples non-parametric test was used for comparing the different groups with respect to both air levels and individual urine sample results. The Wilcoxon twodependent-samples non-parametric test was used for comparing urine sample data between the beginning and the end of the shift. A significance level of 0.05 was applied in all tests.

\section{RESULTS}

\section{Airborne particle concentrations}

Table 1 presents IP and RP results for both incinerators and the control site. Airborne concentrations are similar at the two incinerators for all sizes of particle, and median values are 10 times higher than those measured at the control site. The refuse feed hopper and refuse bunker represented the main sources of emission of inhalable and respirable particles, although IP were also generated during refuse transfer and disposal. Small particles represented only $15-30 \%$ of all particles near sources of emission, but this proportion increased to over $50 \%$ for other workstations at the incinerators and at the control site. While individual exposure to RPs was always less than $10 \%$ of the TLV-TWA, IP exposure can reach $40 \%$ of the TLV-TWA for big-bag operatives, and $65 \%$ when it comes to refuse feed hopper operatives.

\section{Metal air concentrations}

Table 1 presents the concentrations of metals in the air for both incinerators and for the control site. The most common metals at the MWIs were $\mathrm{Pb}$ and $\mathrm{Mn}$. The median value for $\mathrm{Cr}$ was 100 times higher at the MWIs than at the control site, those of $\mathrm{Mn}$ and Cd were 50 times higher, and those of $\mathrm{Pb}$ were 10 times higher. The only level which did not significantly differ between the incinerators and the control site was that of Ni. Whereas $\mathrm{Cd}$ and $\mathrm{Cr}$ levels were comparable at the two incinerators, $\mathrm{Pb}$ concentrations were significantly higher at plant $\mathrm{l}$. The highest $\mathrm{As}, \mathrm{Cd}$, and $\mathrm{Pb}$ levels were found in the residue transfer and disposal area, whereas most of the $\mathrm{Mn}$ was found near the refuse bunker. In contrast, Cr levels were of the same order in the various workstations, except in the flue gas cleaning area where the reading was lower. Individual metal exposure levels did not in any case exceed $8 \%$ of the TLV-TWA, even for the most highly exposed operatives, who were those responsible for the transfer and loading of solid residues into trucks.

\section{Particulate PAH air concentrations}

Table 1 presents particulate PAH concentrations at plant 2 and the control site. The levels found at the MWI were no different from those measured at the control site. The highest concentrations of BaP, PYR, and PAHs were found near the refuse

Table 1 Concentrations of particles, metals, and PAHs in the air at the two incinerators and the control site

\begin{tabular}{|c|c|c|c|c|c|c|c|c|c|}
\hline Substance & $\begin{array}{l}\text { French } \\
\text { TLV-TWA }\end{array}$ & & Incinerators & Plant 1 & Plant 2 & Control site & $\begin{array}{l}\text { Plant } 1 v \\
\text { control }\end{array}$ & $\begin{array}{l}\text { Plant } 2 v \\
\text { control }\end{array}$ & $\begin{array}{l}\text { Plant } 1 \\
v \\
\text { plant } 2\end{array}$ \\
\hline \multicolumn{10}{|l|}{ Particles $\left(\mathrm{mg} / \mathrm{m}^{3}\right)$} \\
\hline \multirow[t]{2}{*}{ Inspirable particles } & 10 & $M \pm S D(n)$ & $1.45 \pm 1.61(34)$ & $1.44 \pm 1.41(15)$ & $1.46 \pm 1.78(19)$ & $0.06 \pm 0.06(6)$ & $p<0.001$ & $p<0.001$ & NS \\
\hline & & $\mathrm{m}$; range & $0.76 ; 0.13-6.43$ & $0.90 ; 0.20-5.22$ & $0.58 ; 0.13-6.43$ & $0.05 ; 0.01-0.17$ & & & \\
\hline \multirow{2}{*}{$\begin{array}{l}\text { Respirable } \\
\text { particles }\end{array}$} & 5 & $M \pm S D(n)$ & $0.39 \pm 0.58(34)$ & $0.30 \pm 0.22(15)$ & $0.46 \pm 0.76(19)$ & $0.03 \pm 0.02(6)$ & $p<0.001$ & $p<0.001$ & NS \\
\hline & & $\mathrm{m}$; range & $0.2 ; 0.03-2.90$ & $0.20 ; 0.07-0.80$ & $0.18 ; 0.03-2.90$ & $0.02 ; 0.02-0.06$ & & & \\
\hline \multicolumn{10}{|l|}{ Metals $\left(\mu \mathrm{g} / \mathrm{m}^{3}\right)$} \\
\hline Arsenic & 200 & $\begin{array}{l}M \pm S D(n) \\
m \text {; range }\end{array}$ & - & - & $\begin{array}{l}0.14 \pm 0.08(20) \\
0.11 ; 0.06-0.43\end{array}$ & $N D(6)$ & & $p<0.001$ & \\
\hline Cadmium & 50 & $\begin{array}{l}M \pm S D(n) \\
m ; \text { range }\end{array}$ & $\begin{array}{l}0.29 \pm 0.62(36) \\
0.07 ; 0.01-3.56\end{array}$ & $\begin{array}{l}0.22 \pm 0.25(16) \\
0.10 ; 0.03-0.98\end{array}$ & $\begin{array}{l}0.34 \pm 0.81(20) \\
0.07 ; 0.01-3.56\end{array}$ & $\begin{array}{l}0.001 \pm 0.001(6) \\
0.001 ; 0.0004-0.003\end{array}$ & $p<0.001$ & $p<0.001$ & NS \\
\hline Chromium & 500 & $\begin{array}{l}M \pm S D(n) \\
m ; \text { range }\end{array}$ & $\begin{array}{l}0.68 \pm 0.67(36) \\
0.43 ; 0.09-2.64\end{array}$ & $\begin{array}{l}0.74 \pm 0.60(16) \\
0.44 ; 0.09-1.81\end{array}$ & $\begin{array}{l}0.64 \pm 0.73(20) \\
0.43 ; 0.10-2.64\end{array}$ & $\begin{array}{l}0.015 \pm 0.019(6) \\
0.006 ; N D-0.044\end{array}$ & $p<0.001$ & $p<0.001$ & NS \\
\hline Lead & 150 & $\begin{array}{l}M \pm S D(n) \\
m ; \text { range }\end{array}$ & $\begin{array}{l}4.73 \pm 7.82(36) \\
0.91 ; 0.09-28.00\end{array}$ & $\begin{array}{l}7.98 \pm 9.32(16) \\
1.43 ; 0.29-28.00\end{array}$ & $\begin{array}{l}2.29 \pm 5.55(20) \\
0.68 ; 0.09-25.47\end{array}$ & $\begin{array}{l}0.078 \pm 0.052(6) \\
0.073 ; 0.027-0.134\end{array}$ & $p<0.001$ & $p<0.001$ & $p<0.05$ \\
\hline Manganese & 1000 & $\begin{array}{l}M \pm S D(n) \\
m ; \text { range }\end{array}$ & - & - & $\begin{array}{l}2.67 \pm 3.33(20) \\
1.53 ; 0.26-13.02\end{array}$ & $\begin{array}{l}0.033 \pm 0.021(6) \\
0.031 ; 0.006-0.065\end{array}$ & & $p<0.001$ & \\
\hline Nickel & 1000 & $\begin{array}{l}M \pm S D(n) \\
m ; \text { range }\end{array}$ & $\begin{array}{l}0.10 \pm 0.27(36) \\
0.03 ; 0.01-1.60\end{array}$ & $\begin{array}{l}0.17 \pm 0.39(16) \\
0.04 ; 0.01-1.60\end{array}$ & $\begin{array}{l}0.05 \pm 0.10(20) \\
0.02 ; 0.01-0.49\end{array}$ & $\begin{array}{l}0.09 \pm 0.15(6) \\
0.04 ; N D-0.39\end{array}$ & NS & NS & $p<0.05$ \\
\hline \multicolumn{10}{|c|}{ 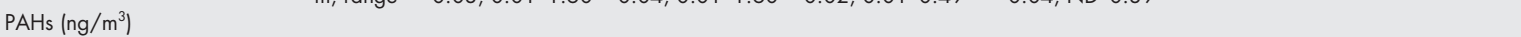 } \\
\hline \multirow[t]{2}{*}{$\mathrm{BaP}$} & 150 & $M \pm S D(n)$ & - & - & $1.09 \pm 2.71$ (19) & $0.43 \pm 0.13(6)$ & & NS & \\
\hline & & $\mathrm{m}$; range & - & - & 0.06 ; ND-11.64 & $0.42 ; 0.28-0.65$ & & & \\
\hline Pyrene & & $\begin{array}{l}M \pm S D(n) \\
m ; \text { range }\end{array}$ & - & - & $\begin{array}{l}5.48 \pm 10.46(19) \\
0.58 ; \mathrm{ND}-91.12\end{array}$ & $\begin{array}{l}6.42 \pm 14.8(6) \\
0.27 ; \mathrm{ND}-36.61\end{array}$ & & NS & \\
\hline $\mathrm{PAHs}$ & & $\begin{array}{l}M \pm S D(n) \\
m ; \text { range }\end{array}$ & & & $\begin{array}{l}18.84 \pm 36.16(19) \\
6.21 ; 0.02-147.46\end{array}$ & $\begin{array}{l}9.68 \pm 16.87(6) \\
2.92 ; 1.20-43.99\end{array}$ & & NS & \\
\hline
\end{tabular}


Table 2 Concentration of aldehydes and VOCs in the air at the two incinerators and the control site

\begin{tabular}{|c|c|c|c|c|c|c|c|c|c|}
\hline $\begin{array}{l}\text { Substances } \\
\left(\mu \mathrm{g} / \mathrm{m}^{3}\right)\end{array}$ & $\begin{array}{l}\text { French } \\
\text { TLV-TWA }\end{array}$ & & Incinerators & Plant 1 & Plant 2 & Control site & $\begin{array}{l}\text { Plant } 1 \mathrm{v} \\
\text { control }\end{array}$ & $\begin{array}{l}\text { Plant } 2 v \\
\text { control }\end{array}$ & $\begin{array}{l}\text { Plant } 1 \\
v \\
\text { plant } 2\end{array}$ \\
\hline \multirow[t]{2}{*}{ Formaldehyde } & 600 & $M \pm S D(n)$ & $11 \pm 9.6(33)$ & $3.4 \pm 1.1(16)$ & $16.9 \pm 9(17)$ & $29.1 \pm 13.7(6)$ & & & \\
\hline & & $\mathrm{m}$; range & $8.5 ; 2-42$ & $4 ; 2-5$ & $15 ; 7-42$ & $33.4 ; 10-45$ & $p<0.001$ & NS & $p<0.001$ \\
\hline \multirow[t]{2}{*}{ Acetaldehyde } & 180000 & $M \pm S D(n)$ & $39.3 \pm 31.3(33)$ & $31.8 \pm 21.9(16)$ & $45.1 \pm 36.6(17)$ & $78 \pm 98.1(6)$ & & & \\
\hline & & $\mathrm{m}$; range & $29 ; 4-140$ & $21 ; 11-78$ & $34 ; 4-140$ & $33.7 ; 7-260$ & NS & NS & NS \\
\hline \multirow[t]{2}{*}{ Aldehydes } & & $M \pm S D(n)$ & $54 \pm 36.3(33)$ & $37.2 \pm 23.5(16)$ & $66.8 \pm 39.6(17)$ & $109.6 \pm 92.1(6)$ & & & \\
\hline & & $\mathrm{m}$; range & $42 ; 15-166$ & $27 ; 16-86$ & $57 ; 15-166$ & $62 ; 40-277$ & $p<0.05$ & NS & $p<0.05$ \\
\hline \multirow[t]{2}{*}{ Alkanes } & & $M \pm S D(n)$ & $453 \pm 601(33)$ & $590 \pm 760(16)$ & $324 \pm 383$ (17) & & & & \\
\hline & & $\mathrm{m}$; range & $124 ; 20-2347$ & $308 ; 30-2347$ & $119 ; 20-1244$ & $N D(6)$ & $p<0.001$ & $p<0.001$ & NS \\
\hline \multirow[t]{2}{*}{ Benzene } & 16000 & $M \pm S D(n)$ & $20 \pm 34(33)$ & $34 \pm 46(16)$ & $7 \pm 4(17)$ & & & & \\
\hline & & $\mathrm{m}$; range & $8 ; 2-147$ & $11 ; 2-147$ & $7 ; 2-17$ & $\mathrm{ND}(6)$ & $p<0.001$ & $p<0.001$ & NS \\
\hline \multirow[t]{2}{*}{ Tolvene } & 375000 & $M \pm S D(n)$ & $430 \pm 636(33)$ & $614 \pm 843(16)$ & $257 \pm 280(17)$ & $81 \pm 79(6)$ & & & \\
\hline & & $\mathrm{m}$; range & $140 ; 35-2677$ & $206 ; 35-2677$ & $107 ; 41-899$ & $42 ; 9-184$ & NS & NS & NS \\
\hline \multirow[t]{2}{*}{ Xylenes } & 435000 & $M \pm S D(n)$ & $223 \pm 388(33)$ & $364 \pm 519(16)$ & $91 \pm 101$ (17) & $21 \pm 38(6)$ & & & \\
\hline & & $\mathrm{m}$; range & $57 ; 9-1948$ & $97 ; 32-1948$ & $35 ; 9-265$ & ND; ND-88 & $p<0.005$ & $p<0.05$ & $p<0.01$ \\
\hline \multirow[t]{2}{*}{ Aromatic hydrocarbons } & & $M \pm S D(n)$ & $774 \pm 1212(33)$ & $1160 \pm 1616(16)$ & $410 \pm 448(17)$ & $169 \pm 135(6)$ & & & \\
\hline & & $\mathrm{m}$; range & $244 ; 60-5506$ & $354 ; 76-5506$ & $154 ; 60-1226$ & $151 ; 9-332$ & NS & NS & NS \\
\hline \multirow[t]{2}{*}{ Dichloromethane } & 360000 & $M \pm S D(n)$ & $283 \pm 680(33)$ & $51 \pm 54(16)$ & $501 \pm 905(17)$ & & & & \\
\hline & & $\mathrm{m}$; range & $73 ; \mathrm{ND}-3775$ & $35 ;$ ND-162 & $121 ; 9-3775$ & ND & $p<0.005$ & $p<0.001$ & $p<0.005$ \\
\hline \multirow[t]{2}{*}{ Chlorinated hydrocarbons } & & $M \pm S D(n)$ & $754 \pm 1237(33)$ & $715 \pm 1197(16)$ & $791 \pm 1309$ (17) & & & & \\
\hline & & $\mathrm{m}$; range & $231 ; 9-5359$ & $229 ; 9-4226$ & $231 ; 23-5359$ & ND & $p<0.001$ & $p<0.001$ & NS \\
\hline \multirow[t]{2}{*}{ Oxygenated hydrocarbons } & & $M \pm S D(n)$ & $883 \pm 1063(33)$ & $1226 \pm 1189(16)$ & $561 \pm 842(17)$ & $710 \pm 770(6)$ & & & \\
\hline & & $\mathrm{m}$; range & $476 ; 5-4253$ & $989 ; 5-4253$ & $364 ; 11-3580$ & $380 ; 244-2068$ & NS & NS & NS \\
\hline \multirow[t]{2}{*}{ VOCs } & & $M \pm S D(n)$ & $2917 \pm 3499(33)$ & $3826 \pm 4350(16)$ & $2061 \pm 2267$ (17) & $881 \pm 880(6)$ & & & \\
\hline & & $\mathrm{m}$; range & $1202 ; 182-13396$ & $1461 ; 182-13396$ & $937 ; 220-8421$ & $457 ; 252-2400$ & NS & NS & NS \\
\hline
\end{tabular}

bunker in the reception hall, where PYR and FLA accounted for $50 \%$ of all PAHs. Individual BaP levels were never greater than $8 \%$ of the TLV-TWA. It should be noted that at the control site, the atmospheric PAH concentration measured in a smoker working in an office was 10 times higher than five of the other values.

\section{Aldehyde air concentrations}

Table 2 presents aldehyde concentrations in the air for both incinerators and for the control site. The levels found at plant 2 were comparable to those at the control site, whereas those measured at plant 1 were significantly lower. Acetaldehyde accounted for more than $80 \%$ of total aldehydes in the MWIs; the highest levels were measured near the refuse feed hopper and the refuse bunker in the reception hall. Individual exposure levels did not exceed 7\% of the TLV-TWA for formaldehyde or $0.1 \%$ of the TLV-TWA for acetaldehyde.

\section{VOC air concentrations}

Table 2 presents VOC concentrations in the air for both incinerators and for the control site. VOC levels found at the MWIs were not significantly higher than those measured at the control site. The main sources of VOC emission were the refuse feed hopper and the refuse bunker. Although the levels of many compounds were higher at plant 1 than at plant 2, the concentration of dichloromethane was higher at the latter. The most highly exposed workers were those operatives who work near the furnaces, but individual levels never exceeded $1 \%$ of the relevant TLV-TWA.

\section{Biological monitoring}

The concentrations of inorganic compounds (table 3) and metabolites of organic compounds (table 4) in the urine of exposed and control subjects at the beginning and at the end of their shifts are presented. In no case (all types of subject and all compounds) was any difference observed between the concentration measured at the beginning of the shift and that measured at the end. However, although the levels of $\mathrm{Cd}, \mathrm{Cr}$, and Ni measured in employees of plant 2 were comparable to those in the controls, significantly higher levels were found in employees of plant 1 . Individual levels at the end of the shift were lower than $25 \%$ of the BEI for Cd and just $2 \%$ of the BEI for Cr. Furthermore, urine levels of Mn found at plant 2 were comparable to those at the control site, whereas those of As were significantly higher. Individual As levels could reach 65\% of the BEI. The urinary metabolite levels of the organic compounds were well below the BEI, and there was no difference between MWI workers and control subjects.

\section{DISCUSSION}

The pollutants which were found at higher concentrations in a MWI environment-compared with the concentrations measured at control sites or, in a more general way, in a representative urban setting ${ }^{22}$-were particles and metals. The IP concentrations measured in this work are similar to those measured in another recent study, ${ }^{23}$ whereas levels of RPs are lower than those reported for older facilities in which the effluent treatment systems were less efficient. ${ }^{24}$ Individual exposure levels for different employees vary a great deal because of the effect of the kind of cleaning operations carried out at different workstations, notably in the reception hall, at the refuse feed hopper platform, the amount of refuse recovery after it has fallen off the feed table, and the cleaning of bottom ash refuse jammed in the feed chutes or on the vibrating conveyors. Nevertheless, these levels are still well below those measured during furnace maintenance operations during which IP and RP levels can reach 350 and $10 \mathrm{mg} / \mathrm{m}^{3}$ respectively. ${ }^{25}$ Although IP-unlike $\mathrm{RP}$ - cannot penetrate as far as the pulmonary alveoli, they can nevertheless cause irritation and non-specific inflammation in the upper airways in synergy with other pollutants such as oxidising agents or microorganisms. ${ }^{26}$ Although such mechanisms are believed to be involved in triggering acute and subacute respiratory problems, little effect on respiratory function could be detected in MWI workers, probably because of the small number of subjects who are directly exposed to these sources of emission. $^{14} 15$

Of the metals investigated, those found at the highest concentrations in MWI workers were primarily $\mathrm{Pb}$ and $\mathrm{Mn}$, followed by $\mathrm{Cr}$ and $\mathrm{Cd}$, and finally As and Ni. These results are entirely consistent with the chemical profiles of bottom and fly ashes which represent the main source of metal emission from incinerators. The higher levels of $\mathrm{Pb}$ found at plant $\mathrm{l}$ are consistent with the site data which show that the residues from plant 2 contain $25 \%$ less of this element. This differential 
Table 3 Urine concentration of inorganic compounds measured at the beginning and at the end of shifts of MWI workers and control subjects

\begin{tabular}{|c|c|c|c|c|c|c|c|c|c|c|}
\hline $\begin{array}{l}\text { Substances } \\
\mu \mathrm{g} / \mathrm{g} \text { creat }\end{array}$ & $\begin{array}{l}\text { French BEl } \\
\mu \mathrm{g} / \mathrm{g} \text { creat }\end{array}$ & & & Incinerators & Plant 1 & Plant 2 & Control site & $\begin{array}{l}\text { Plant } 1 v \\
\text { control }\end{array}$ & $\begin{array}{l}\text { Plant } 2 v \\
\text { control }\end{array}$ & $\begin{array}{l}\text { Plant } 1 \mathrm{v} \\
\text { plant } 2\end{array}$ \\
\hline \multirow[t]{4}{*}{ Arsenic } & 50 & BS & $M \pm S D(n)$ & - & - & $10.88 \pm 8.17(14)$ & $3.06 \pm 2.31(17)$ & & $p<0.001$ & \\
\hline & & & $\mathrm{m}$; range & - & - & $9.17 ; 2.47-32.76$ & $2.15 ; 0.37-9.15$ & & & \\
\hline & & ES & $M \pm S D(n)$ & & & $8.94 \pm 7.48(14)$ & $3.29 \pm 2.37(17)$ & & $p<0.005$ & \\
\hline & & & $\mathrm{m}$; range & & & $\begin{array}{l}6.41 ; 1.82-26.87 \\
(N S)^{*}\end{array}$ & $\begin{array}{l}3.13 ; 0.35-9.83 \\
\text { (NS)* }\end{array}$ & & & \\
\hline \multirow[t]{4}{*}{ Cadmium } & 5 & BS & $M \pm S D(n)$ & $0.53 \pm 0.55(29)$ & $0.73 \pm 0.64(15)$ & $0.32 \pm 0.36(14)$ & $0.33 \pm 0.36(17)$ & $p<0.005$ & NS & $p<0.005$ \\
\hline & & & $\mathrm{m}$; range & $0.40 ; 0.05-2.63$ & $0.51 ; 0.17-2.63$ & $0.21 ; 0.05-1.44$ & $0.20 ; 0.11-1.65$ & & & \\
\hline & & ES & $M \pm S D(n)$ & $0.39 \pm 0.26(29)$ & $0.52 \pm 0.25(15)$ & $0.26 \pm 0.20(14)$ & $0.32 \pm 0.30(17)$ & $p<0.005$ & NS & $p<0.005$ \\
\hline & & & $\mathrm{m}$; range & $\begin{array}{l}0.37 ; 0.08-1.09 \\
(N S)^{*}\end{array}$ & $\begin{array}{l}0.44 ; 0.15-1.09 \\
\text { (NS)* }\end{array}$ & $\begin{array}{l}0.19 ; 0.08-0.78 \\
(\mathrm{NS}) \text { * }\end{array}$ & $\begin{array}{l}0.21 ; 0.08-1.34 \\
\text { (NS)* }\end{array}$ & & & \\
\hline \multirow[t]{4}{*}{ Chromium } & 30 & BS & $M \pm S D(n)$ & $0.36 \pm 0.53(29)$ & $0.59 \pm 0.66(15)$ & $0.11 \pm 0.13(14)$ & $0.11 \pm 0.06$ (17) & $p<0.001$ & NS & $p<0.001$ \\
\hline & & & $\mathrm{m}$; range & $0.14 ; 0.03-2.63$ & $0.38 ; 0.12-2.63$ & $0.08 ; 0.03-0.56$ & $0.08 ; 0.04-0.28$ & & & \\
\hline & & ES & $M \pm S D(n)$ & $0.23 \pm 0.18(29)$ & $0.36 \pm 0.14(15)$ & $0.08 \pm 0.04(14)$ & $0.12 \pm 0.09$ (17) & $p<0.001$ & NS & $p<0.001$ \\
\hline & & & $\mathrm{m}$; range & $\begin{array}{l}0.17 ; 0.04-0.60 \\
\text { (NS)* }\end{array}$ & $\begin{array}{l}0.37 ; 0.15-0.60 \\
(\mathrm{NS}) *\end{array}$ & $\begin{array}{l}0.07 ; 0.04-0.19 \\
(N S) *\end{array}$ & $\begin{array}{l}0.08 ; 0.03-0.38 \\
\text { (NS)* }\end{array}$ & & & \\
\hline \multirow[t]{4}{*}{ Manganese } & & BS & $M \pm S D(n)$ & - & - & $0.97 \pm 0.98(14)$ & $0.87 \pm 0.58(17)$ & & NS & \\
\hline & & & $\mathrm{m}$; range & - & - & $0.45 ; 0.20-3.60$ & $0.83 ; 0.18-2.08$ & & & \\
\hline & & ES & $M \pm S D(n)$ & & & $0.71 \pm 0.88(14)$ & $1.08 \pm 0.89(17)$ & & NS & \\
\hline & & & $\mathrm{m}$; range & & & $\begin{array}{l}0.45 ; 0.30-3.70 \\
(N S)^{*}\end{array}$ & $\begin{array}{l}0.97 ; 0.08-3.24 \\
\text { (NS)* }\end{array}$ & & & \\
\hline \multirow[t]{4}{*}{ Nickel } & & BS & $M \pm S D(n)$ & $3.89 \pm 5.38(29)$ & $5.74 \pm 6.63(15)$ & $1.91 \pm 2.63(14)$ & $1.07 \pm 0.64(17)$ & $p<0.001$ & NS & $p<0.001$ \\
\hline & & & $\mathrm{m}$; range & $2.33 ; 0.38-26.32$ & $3.79 ; 1.22-26.32$ & $0.81 ; 0.38-8.33$ & $0.79 ; 0.44-3.14$ & & & \\
\hline & & ES & $M \pm S D(n)$ & $2.60 \pm 1.74(29)$ & $3.59 \pm 1.43(15)$ & $1.55 \pm 1.42(14)$ & $1.01 \pm 0.55$ (17) & $p<0.001$ & NS & $p<0.001$ \\
\hline & & & $\mathrm{m}$; range & $\begin{array}{l}2.00 ; 0.45-5.95 \\
\text { (NS)* }\end{array}$ & $\begin{array}{l}3.70 ; 1.47-5.95 \\
(N S)^{*}\end{array}$ & $\begin{array}{l}0.98 ; 0.45-4.76 \\
(\mathrm{NS}) *\end{array}$ & $\begin{array}{l}0.84 ; 0.43-2.50 \\
\text { (NS)* }\end{array}$ & & & \\
\hline
\end{tabular}

may be explained by differences in the nature of the refuse being incinerated; the main sources of $\mathrm{Pb}$ are the neck coverings of wine bottles, solder for electronic components, and non-ferrous metal wastes. The atmospheric metal concentrations recorded in this study are lower than those measured at older facilities, ${ }^{24}$ and although current atmospheric exposure levels do not result in any increase in urine concentrations of the metals studied during the actual shift, they may nevertheless explain certain differences observed over the longer term between the employees at the two incinerators. Plant 2 was recently constructed from scratch, whereas plant $\mathrm{l}$ is in the process of renovation, with one old furnace about to be decommissioned but still functioning. This is the most likely explanation of why employees at plant 1 have higher chronic urine concentrations than those at plant 2 . The urine results in this study are compatible with those reported recently in other studies, ${ }^{27}{ }^{28}$ with all levels well below the existing occupational BEI. If the results are considered in the light of the background levels of exposure of the general population, it can be seen that the measurements in the employees at plant 2-except for As-and the control subjects are comparable to the reference values, whereas the levels in the employees of plant 1 are higher. ${ }^{29}$ It is unfortunate that As was not measured at plant 1 , because air and urinary levels were probably higher than those at plant 2 . Nevertheless, levels of As were very low, like levels of the other measured metals, and potential carcinogenic exposure due to $\mathrm{Cr}$ was lower than that reported. Indeed, only hexavalent $\mathrm{Cr}$ and not total $\mathrm{Cr}$ as measured in the present study is carcinogenic. Given the long term exposure to low concentrations of metals experienced by the employees, whether or not there is any increased

Table 4 Urine concentration of organic compounds measured at the beginning and at the end of the shifts of MWI workers and control subjects

\begin{tabular}{|c|c|c|c|c|c|c|c|c|c|c|}
\hline Substances & French BEI & & & Incinerators & Plant 1 & Plant 2 & Control site & $\begin{array}{l}\text { Plant } 1 v \\
\text { control }\end{array}$ & $\begin{array}{l}\text { Plant } 2 v \\
\text { control }\end{array}$ & $\begin{array}{l}\text { Plant } 1 v \\
\text { plant } 2\end{array}$ \\
\hline 1-HP & & BS & $M \pm S D(n)$ & - & - & $0.16 \pm 0.31(14)$ & $0.14 \pm 0.17(17)$ & - & NS & - \\
\hline \multirow[t]{3}{*}{$\mu g / g$ creat } & & & $\mathrm{m}$; range & - & - & $0.06 ; 0.02-1.20$ & $0.07 ; 0.02-0.62$ & & & \\
\hline & & ES & $M \pm S D(n)$ & & & $0.09 \pm 0.07(14)$ & $0.14 \pm 0.20$ (17) & - & & - \\
\hline & & & $\mathrm{m}$; range & & & $\begin{array}{l}0.06 ; 0.02-0.25 \\
(\mathrm{NS})^{*}\end{array}$ & $\begin{array}{l}0.07 ; 0.01-0.73 \\
(\mathrm{NS})^{*}\end{array}$ & & NS & \\
\hline TMA & & BS & $M \pm S D(n)$ & - & - & $0.05 \pm 0.06(14)$ & $0.04 \pm 0.03$ (17) & & & \\
\hline \multirow[t]{3}{*}{$\mathrm{mg} / \mathrm{g}$ creat } & $5 \mathrm{mg} / \mathrm{l}$ & & $\mathrm{m}$; range & - & - & $0.04 ; 0.01-0.16$ & $0.02 ; 0.01-0.14$ & - & NS & NS \\
\hline & & ES & $M \pm S D(n)$ & & & $0.06 \pm 0.06(14)$ & $0.05 \pm 0.03(17)$ & & & \\
\hline & & & $\mathrm{m}$; range & & & $\begin{array}{l}0.05 ; 0.02-0.2 \\
(\mathrm{NS})^{*}\end{array}$ & $\begin{array}{l}0.03 ; 0.01-0.18 \\
(\mathrm{NS})^{*}\end{array}$ & - & NS & NS \\
\hline & & BS & $M \pm S D(n)$ & $54.8 \pm 63.6(29)$ & $58.0 \pm 79.4(15)$ & $51.5 \pm 45.4(14)$ & $33.3 \pm 17.4(17)$ & & & \\
\hline \multirow[t]{3}{*}{$\mu \mathrm{g} / \mathrm{g}$ creat } & & & $\mathrm{m}$; range & $25.8 ; 8.6-278.8$ & $25.5 ; 12.95-278.8$ & $26.9 ; 8.6-138.9$ & $27.7 ; 17.6-88.24$ & NS & NS & NS \\
\hline & & ES & $M \pm S D(n)$ & $82.4 \pm 168.5(29)$ & $111.8 \pm 227.2(15)$ & $51.0 \pm 59.2(14)$ & $33.6 \pm 25.6(17)$ & & & \\
\hline & & & $\mathrm{m}$; range & $\begin{array}{l}22.9 ; 7.3-882.2 \\
\text { (NS) }{ }^{*}\end{array}$ & $\begin{array}{l}24.5 ; 7.3-882.2 \\
(N S)^{*}\end{array}$ & $\begin{array}{l}18.2 ; 10.6-184 \\
(\mathrm{NS})^{*}\end{array}$ & $\begin{array}{l}25 ; 11.8-119 \\
(N S)^{*}\end{array}$ & NS & NS & NS \\
\hline & & BS & $M \pm S D(n)$ & $7.8 \pm 8.5(29)$ & $8.4 \pm 9.02(15)$ & $7.2 \pm 8.3(14)$ & $6.7 \pm 5.3(17)$ & & & \\
\hline \multirow[t]{3}{*}{$\mathrm{mg} / \mathrm{g}$ creat } & $1.5 \mathrm{~g} / \mathrm{g}$ creat & & $\mathrm{m}$; range & $3.9 ; 1.1-28.3$ & $3.9 ; 1.1-28.3$ & $3.9 ; 1.7-27.8$ & $4.8 ; 1.8-21.8$ & NS & NS & NS \\
\hline & & ES & $M \pm S D(n)$ & $7.4 \pm 9.4(29)$ & $8.8 \pm 11.0(15)$ & $5.9 \pm 7.3(14)$ & $5.6 \pm 5.1(17)$ & & & \\
\hline & & & $\mathrm{m}$; range & $\begin{array}{l}3.7 ; 1.5-37.3 \\
(\mathrm{NS}) \text { * }\end{array}$ & $\begin{array}{l}3.9 ; 1.5-37.3 \\
(\mathrm{NS}) \text { * }\end{array}$ & $\begin{array}{l}3.4 ; 2.1-30.2 \\
\text { (NS) * }\end{array}$ & $\begin{array}{l}3.9 ; 1.7-23.8 \\
(\mathrm{NS}))^{*}\end{array}$ & NS & NS & NS \\
\hline
\end{tabular}


incidence of malignancy in this population is an important question-all the more so since mutagenic activity has previously been shown in the urine of incinerator workers. ${ }^{16}$ Unfortunately, little epidemiological data has been collected in this occupational setting, and no firm conclusions can be drawn from the small amount of information available. ${ }^{17}$

Apart from chlorinated hydrocarbons, levels of none of the VOCs were more than 10 times higher in incinerators than at control sites. Chlorinated hydrocarbons are released during the burning of plastics ${ }^{30}$; large quantities of dichloromethane were found at plant 2 where, in contrast to plant 1 , no preliminary refuse sorting is carried out. However, all levels still remain well below the corresponding occupational TLVs. Although atmospheric benzene levels are higher than the mean annual values for an urban environment, ${ }^{22}$ they are comparable to those experienced by traffic policemen working in the centre of Grenoble in winter. ${ }^{31}$ The fact that occupational exposure levels are so low, coupled with the rapid kinetics of elimination of VOC metabolites, explain firstly why no difference was measured in urine concentrations between the beginning and the end of the shift, and secondly why no difference was detected between MWI workers and controls or other subjects who are not exposed to particularly high levels of such compounds in the course of their work. ${ }^{29}$ In addition to the combustion gases (the highest levels of which are found near the refuse feed hopper), the evaporation of volatile compounds in the refuse bunker could contribute to the VOC levels measured in the reception hall, especially when it comes to the kinds of alcohols, esters, and ketones which are derived from the breakdown of biodegradable wastes by microorganisms. As well as the VOCs analysed in this study, anaerobic microbial bioconversion is known to generate large amounts of organosulphur compounds, including dimethyl sulphide and, particularly significantly, oxygenated and strong smelling monoterpenes. ${ }^{30}$ Although low levels of VOCs in the air do not appear to pose a significant threat to public health at this point in time, these sulphurous gases may contribute to upper airway irritation and nausea, especially in workers who handle household waste in sorting centres.

Atmospheric levels of particulate PAHs and aldehydes are no higher in incinerators than at the control site or in an average urban environment, and are entirely comparable to those experienced by traffic policemen working in the centre of Grenoble in winter. ${ }^{22}{ }^{31}$ The highest concentrations of PAHs and aldehydes were measured around the refuse bunker. Most of these pollutants emanate from the garbage trucks driving through the reception hall to park at the refuse bunker unloading platform. Although big incineration units with efficient pollution control equipment mean less atmospheric pollution, they also concentrate the chemical and noise pollution associated with heavy truck traffic. The low occupational exposure to PAHs measured in this study explains why urine 1-HP concentrations are no higher in MWI workers than in control subjects. These results are identical to those obtained in other recent studies of incinerator workers, ${ }^{27}{ }^{32}$ but the levels are lower than those measured in garbage collection operatives who tend to be much more heavily exposed to vehicle exhaust. ${ }^{33}$ While aldehydes at higher levels of exposure than those dealt with in this study are known to be instrumental in triggering acute respiratory disease, the effects of long term exposure to low doses of particulate PAHs are not definitively known, and a role in the development of malignancy cannot be ruled out.

In conclusion, air monitoring in MWIs and biological monitoring of MWI workers provides evidence that occupational exposure does not result in the infringement of any currently applicable occupational-medical TLV. Air monitoring remains the only method that makes it possible to identify the primary sources of pollutant emission, and all preventative modalities should be based first and foremost on the results of this kind of monitoring. The results of biological assays before and after exposure to toxic pollutants are not a reliable way of assessing occupational exposure in MWI workers because of the low overall exposure levels. If biological monitoring remains an easy way of acquiring data on personal exposure, validation is still warranted for assessing the long term impact of incineration on employee health.

Concentrations of VOCs and aldehydes in the air were low and do not appear to pose a significant threat to human health. Only the measurement of chlorinated hydrocarbon levels (which are a good marker for the products of the combustion of plastics) would seem to be of use in this context. When it comes to particulate pollution, MWI workers are not more highly exposed to PAHs than any other workers who are regularly in contact with vehicle exhaust. The only times MWI workers are exposed to levels of pollutants which are 10-100 times higher than controls concern exposure to particles during cleaning operations and to metals during residue transfer and disposal operations. These levels might be higher in incinerators which fail to meet current norms and also during certain special operations such as furnace maintenance; respiratory protection ought to be worn when carrying out any of these high risk activities in order to cut down exposure and thereby reduce the incidence of respiratory disease, and in the longer term and even more importantly, the risk of cancer. Recent incinerators in which the effluent treatment systems are efficient should be considered as a good alternative waste management practice to landfills.

\section{ACKNOWLEDGEMENTS}

This study was supported by the Ministry of Labor, the Cancer Research Association, and l'Agence de l'Environnement et de la Maîtrise de l'Energie. We are grateful to Mrs S Liaudy for documentational research, and to physicians, directors, and operators of the plants involved in the study

\section{Authors' affiliations}

A Maître, D Collot-Fertey, M Marques, M Stoklov, Department of Occupational Medicine, EPSP-TIMC (Environnement et Prédiction de la Santé des Populations) Laboratory, Grenoble Faculty of Medicine, Joseph Fourier University, Domaine de la Merci, 38700 La Tronche, France L Anzivino, M Hours, University Institute of Occupational Medicine, UMRETTE-Université Claude Bernard Lyon I /INRETS, Domaine Rockefeller, 69373 Lyon Cedex 08, France

\section{REFERENCES}

1 ADEME (Agence de l'environnement et de la maîtrise de I'énergie). Le traitement des déchets ménagers et assimilés en centres collectifs en 1995. Paris: ADEME, 1997.

2 Gochfeld $\boldsymbol{M}$. Incineration: health and environmental consequences. Mount Sinai J Med 1995;62:365-74

3 International Agency for Research on Cancer. Overall evaluations of carcinogenicity to humans. As evaluated in IARC monographs volumes 1-77. Lyon: IARC, September 2001.

4 Williams FLR, Lawson AB, Lloyd OL. Low sex ratios of births in areas at risk from air pollution from incinerators, as shown by geographical analysis and 3-dimensional mapping. Int J Epidemiol 1992:21:311-19.

5 Shy C, Degnan D, Fox DL, et al. Do waste incinerators induce adverse respiratory effects? An air quality and epidemiological study of six communities. Environ Health Perspect 1995;103:714-24.

6 Elliott P, Shaddick G, Kleinschmidt I, et al. Cancer incidence near municipal waste incinerators in Great Britain. Br J Cancer 1996;73:702-10

7 Biggeri A, Barbone F, Lagazio C, et al. Air pollution and lung cancer in Trieste, Italy: spatial analysis of risk as a function of distance from sources. Environ Health Perspect 1996;104:750-4.

8 Viel JF, Arveux P, Baverel J, et al. Soft-tissue sarcoma and non-hodgkin's lymphoma clusters around a municipal solid waste incinerator with high dioxin emission levels. Am J Epidemiol 2000;152:13-19.

9 Hallenbeck WH, Breen SP, Brenniman GR. Cancer risk assessment for the inhalation of metals from municipal solid waste incinerators impacting Chicago. Bull Environ Contam Toxicol 1993:51:165-70.

10 Boudet C, Zmirou D, Laffond M, et al. Health risk assessment of a modern municipal waste incinerator. Risk Anal 1999;19:1215-22.

11 Elliott P, Eaton N, Shaddick, et al. Cancer incidence near municipal solid waste incinerators in Great Britain. Part 2: histopathological and case-note review of primary liver cancer cases. $\mathrm{Br} J$ Cancer 2000;82: $1103-6$. 
12 Koblantz SM, Teiger DG, Kitto ME, et al. Impact assessment of emissions from a municipal waste incinerator. Environ Monit Assess 1997;45:21-42.

13 Besombes JL, Maître A, Patissier O, et al. Particulate PAHs observed in the surrounding of a municipal incinerator. Atmos Environ 2001;35:6093-104.

14 Bresnitz EA, Roseman J, Becker D, et al. Morbidity among municipal waste incinerator Workers. Am J Ind Med 1992;22:363-78.

15 Boswell RT, McCunney RJ. Bronchiolitis obliterans from exposure to incinerator fly ash. J Occup Environ Med 1995;37:850-5.

16 Ma XF, Babish JG, Scarlett JM, et al. Mutagens in urine sampled repetitively from municipal refuse incinerator workers and water treatment workers. J Toxicol Environ Health 1992;37:483-94.

17 Rapiti E, Sperati A, Fano V, et al. Mortality among workers at municipal waste incinerator in Rome: a retrospective cohort study. Am J Ind Med 1997;31:659-61.

18 Gustavsson P. Mortality among workers at a municipal waste incinerator. Am J Ind Med 1989;15:45-53

19 Gustavsson P, Jakobsson R, Nyberg F, et al. Occupational exposure and lung cancer risk: a population-based case referent study in Sweden. Am J Epidemiol 2000;152:32-40.

20 Hours M, Anzivino-Viricel L, Maître A, et al. Morbidity among municipal waste incinerator workers: a cross-sectional study. Int Arch Environ Occup Health 2003;76: (online first in link.springer.de [abstract 10.1007]).

21 Maître A, Stoklov M. Places et limites des prélèvements atmosphériques et des indicateurs biologiques d'exposition. In: Encycl Med Chir, Toxicologie-Pathologie Professionnelle. Elsevier: Paris, 1999:16001-B-10.

22 World Health Organisation. Air quality guidelines for Europe. WHO European series, no. 91. Copenhagen: WHO Regional Publications, 2000.
23 Mahar S, Reynolds SJ, Thorne PS. Worker exposures to particulates endotoxins, and bioaerosols in two refuse-derived fuel plants. Am Ind Hyg Assoc 1999;60:679-83.

24 Mozzon D, Brown DA, Smith JW. Occupational exposure to airborne dust, respirable quartz and metels arising from refuse handling, burning and landfilling. Am Ind Hyg Assoc 1987;48:111-16.

25 Manrique N, Stoklov M, Richioud M, et al. Exposition aux HAP pendant la maintenance des fours des usines $d^{\prime}$ incinération $d^{\prime}$ 'ordures ménagères. Abstract of paper presented at XXVle National Congress of Occupational Medicine. Arch Mal Prof 2001;62:203-4.

26 American Thoracic Society. Health effects of outdoor air pollution. Am J Respir Crit Care Med 1996;153:3-50.

27 Wrbitzky R, Göen T, Letzel S, et al. Internal exposure of waste incineration workers to organic and inorganic substances. Int Arch Occup Environ Health 1995:68:13-21.

28 Gonzales CA, Kogevinas M, Gadea E, et al. Biomonitoring study of people living near or working at a municipal solid-waste incinerator before and after two years of operation. Arch Environ Health 2000;55:259-67.

29 Lauwerys RR, Hoet P. Industrial chemical exposure: guidelines for biological monitoring. Boca Raton: Lewis, 2001.

30 Wilkins K. Gaseous organic emissions from various types of household waste. Ann Agric Environ Med 1997;4:87-9.

31 Maître A, Soulat JM, Masclet $P$, et al. Individual exposure to carcinogenic air pollutants of police officers working close to traffic in urban area. Scand J Work Environ Health 2002; 28:402-10.

32 Göen T, Gündel, Schaller KH, et al. The elimination of 1-hydroxypyrene in the urine of the general population and workers with different occupational exposures to PAH. Sci Tot Environ 1995;163:195-201.

33 Hara K, Hanaoka T, Yamano Y, et al. Urinary 1-hydroxypyrene levels of garbage collectors with low-exposure to polycyclic aromatic hydrocarbons. Sci Tot Environ 1997; 199:159-64.

\section{$\mathrm{ECHO}$}

Researchers must take safety programmes into the workplace

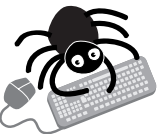

Please visit the Occupational and

Environmental Medicine website (www. occenvmed.com for link to this full article.
$\mathrm{N}$ ow is the time for researchers to take the next crucial step to preventing occupational injury and join with industry, employers, and workers to implement injury prevention practices, exhorts a review of occupational injury prevention in the United States.

Occupational deaths are declining. The National Traumatic Occupational Fatalities Surveillance System, probably the best source of recent trend data, estimates that during 1980-98 the annual rate of occupational deaths fell from over 7.5/100 000 workers to just under 4/100 000 workers. The Census of Fatal Occupational Injuries reported fewer than 6000 deaths in the United States in 2000. Nevertheless, closer inspection discloses that death rates among the leading causes of occupational deaths-from motor vehicles, murder, machines, falls, and electrocutions - are falling at different rates and in some industries are actually increasing.

Progress has largely been the result of applying science based problem solving to occupational injury and death and, latterly, to more collaboration between government and industry and among public health, safety, and social scientists. What is now needed is for occupational injury researchers to help industry overcome barriers to changing working practice. This entails focusing on evaluating safety programmes, showing their practical and cost effectiveness; breaking down psychological and organisational barriers; and speeding the take up of programmes by key decision makers in organisations-maybe seeking to influence the "early adopters" first.

These are immediate priorities. Occupational injury researchers have an important responsibility: "to find the means to apply what we know so that the real end result is the worker who goes home alive and safe at the end of the day."

A Injury Prevention 2002;8(Suppl IV):iv9-iv14. 